\title{
Результати застосування програми фізичної терапії із залученням методик етнічного масажу при ушкодженнях гомілковостопного суглобу
}

\author{
Юсеф Шарбель \\ Тетяна Підкопай \\ Денис Підкопай
}

Харківська державна академія фізичної культури,

Харків, Україна

Мета: оцінка результатів фізичної терапії спортсменів футболістів з внутрішньосуглобовими ушкодженнями гомілковостопного суглоба на амбулаторному етапі при застосуванні заходів програми фізичної терапії із залученням методик етнічного східного масажу.

Матеріал і методи: в роботі проаналізовані результати дослідження, які проводилися в м. Бейрут(Ліван), клініці Медичного центру «Mir Majid Erslan». Ефективність фізичної терапії 36 футболістів з внутрішньосуглобовими ушкодженнями гомілковостопного суглобу на амбулаторному етапі оцінювали за методикою А.В. Калашнікова та за шкалою LEFS.

Результати: встановлено, що при позитивних змінах функціонального стану постраждалих спортсменів обох клінічних груп достовірно кращими є результати, що були отримані футболістами основної групи, яким була запропонована фізична терапія згідно з розробленою нами програмою.

Висновки: проведений аналіз результатів дослідження показав, що у травмованих спортсменів основної групи, при однакових термінах та об'ємах спостереження, результати методів дослідження були достовірно вищими та об'єктивно більш вираженими, ніж у контрольній групі.

Ключові слова: внутрішньосуглобові ушкодження гомілковостопного суглобу, фізична терапія, східний масаж, східна лазня, амбулаторний етап.

\section{Вступ}

У дослідженні, яке тривало понад 16 років, Ј. М. Hootman et al. [15] спостерігали за спортсменами 15 різних видів спорту в США та дійшли висновку, що травми нижніх кінцівок складають більше $50 \%$ усіх спортивних травм, водночас уражаються переважно коліно та кісточки. Більшість травм були контактними, причому під час змагань спостерігалася значно більша кількість травм порівняно з тренуваннями. 315 видів спорту футбол мав найвищий рівень травматизму, другою за кількістю травм була змагальна боротьба.

Найпоширенішим типом переломів у ГСС в усіх вікових групах є перелом зовнішньої кісточки, частота якого сягає 55\% усіх переломів кісточок. Кісточки є однією 3 найрозповсюдженіших локалізацій травми у 24 з 70 видів спорту. Причинами травм у $61 \%$ випадків є падіння, у 22 $\%$ - заняття спортом [14]. Не дивлячись на те, що у більшості випадків спостерігається повне відновлення функції ГСС після цього виду травм, близько половини пацієнтів, попри повне одужання, повідомляють про постійні проблеми з фізичним і психологічним здоров'ям [16].

Масаж широко застосовують при терапії хворих 3 переломами різної локалізації. Лікувальна дія масажу полягає у механічному впливі на шкіру, м'язи, сухожилля, капсульно-зв'язковий апарат суглобів, лімфатичні судини. До того ж під впливом масажу у корі головного мозку розвиваються складні процеси, викликаючи в системах організму й органах відповідні реактивні відповіді [2].
Дія масажу на організм відбувається через механічні подразнення тканин за допомогою спеціальних прийомів: погладжування, розтирання, розминання, ударні прийоми, вібрація. Масаж діє на організм комплексно, оскільки будь-яке подразнення, викликане прийомами масажу, діє не лише в місці безпосередньої дії, а й опосередковано впливає на стан організму в цілому [1].

Лікувальний вплив масажу на систему кровообігу, зв'язково-м'язовий та суглобовий апарат організму людини відбувається через рефлекторні зв'язки. Терапевтичний вплив масажу проявляється у поліпшенні кровопостачання й трофіки тканин, що запобігає розвитку м'язової гіпотрофії. Відомо, що масаж сприяє поліпшенню скорочувальної здатності м'язів і підвищує їх еластичність, впливає на тонус м'язів [8].

Масаж прискорює регенерацію кісткової тканини, оскільки його прийоми збільшують кровопостачання зони, яка зазнала травми. Цим пояснюється вимога якомога більш раннього застосування масажу у відновлювальному періоді після травм [10].

Терапевтичний ефект лікувального масажу при терапії після ушкоджень стопи та ГСС призводить до клінічно значущих поліпшень функції суглоба, збільшення його рухливості та амплітуди руху [7].

E. E. Painter et al. [17] спостерігали поліпшення рухів ГСС, зменшення болю в суглобі у травмованих спортсменів після іммобілізації при стабільних переломах ГСС в середньому через 6 сеансів масажу, водночас біль- 
шість травмованих спортсменів відзначило поліпшення вже через 4 тижні.

M. S. Crowell et al. [13] звернули увагу на необхідність індивідуального підходу до травмованого спортсмена, що ґрунтується не на протоколі лікування, а ухваленні рішення, яке спирається на оцінку реакції травмованого спортсмена на кожен прийом масажу, збільшуючи ступінь або тривалість прийомів, які надавали бажаний ефект.

Застосування етнічних напрямів східного масажу в літературі описано дещо фрагментарно, частіше у відновних та рекреаційних цілях, але фізіологічна дія прийомів східного масажу вважається достатньо вираженою та спрямованою. Використання прийомів східного масажу для репаративного впливу на структури суглобів, фасціальні і періартикулярні тканини при вірному технічному та методичному застосуванні, за даними Меркаті М.(2002), та Ламбера Дж. (2005), є дієвим впливом на процес повернення та збільшення пасивної гнучкості більшості суглобів тіла людини, особливо великих суглобів хребта і нижніх кінцівок. Виконання процедури східного масажу, за даними авторів, має певні обмеження за віком та медичними протипоказами (для осіб, старших за 60 років, наявність гострих або хронічних захворювань суглобів тощо), які мають бути враховані за допомогою змінення амплітуди та інтенсивності виконання масажних прийомів, добором прийомів масажу та тривалістю процедури [5].

Окремо фахівці наголошують на доцільності комбінування масажу, особливо процедур східного масажу із тепловими процедурами (лазневими процедурами) при лікуванні травматичних і запальних захворюваннях зв'язкового та м'язового апарату у підгострому періоді, а також при хронічних процесах, тугорухомості суглобів, м'язових контрактурах, судинних розладах, можливості спазмів. При функціональних порушеннях опорно-рухового апарату, до яких належать: тугорухомість суглоба, артикулярні зрощення, сповільнене утворення кісткової мозолі, м'язова атрофія, парези, неврити, невралгії, у реабілітаційній практиці рекомендується спочатку застосовувати тепло, а потім процедуру масажу із застосуванням прийомів масажу з амплітудними рухами у суглобах, що виразно використовується у техніці східного (тайського) масажу [6].

Викладене свідчить про значну увагу до означеної проблеми та можливість створення ефективних програм фізичної терапії спортсменів з внутрішньосуглобовими ушкодженнями гомілковостопного суглоба на амбулаторному етапі із залученням методик етнічного масажу.

Мета дослідження - оцінка результатів фізичної терапії спортсменів футболістів з внутрішньосуглобовими ушкодженнями гомілковостопного суглоба на амбулаторному етапі при застосуванні заходів програми фізичної терапії із залученням методик етнічного масажу.

\section{Матеріал і методи дослідження}

Дослідження здійснювалося на базі Медичного центру «Mir Majid Erslan» М. Бейрут (Ліван) в кабінеті фізичної терапії з 2016 по 2018 роки. У дослідженні брали участь 36 спортсменів футболістів. Усі постраждалі спортсмени були чоловічої статі, віком від 18 до 24 років. Спортсмени, що отримали травму, були поділені на основну групу та групу контролю (по 18 осіб у кожній). За проявами функціональних порушень, локалізацією отриманих ушкоджень, віком та рівнем спортивної кваліфікації основна й контрольна група були тотожними.

Давність травми спортсменів, які брали участь у дослідженні, складала 4-6 місяців. Постраждалі спортсмени основної клінічної групи проходили курс фізичної терапії одночасно з поновленням тренувального процесу.

У дослідженні брали участь травмовані спортсмени із закритими ушкодженнями гомілковостопного суглобу типів A1, A2, C1 та C2 за класифікацією AO/ASIF [18].

Травмовані спортсмени з обох груп проходили первинне й повторне обстеження - безпосередньо перед фізичною терапією та при його завершенні, а саме за 30 днів після його початку, що давало змогу об'єктивно оцінити динаміку змін показників методів дослідження.

Ефективність фізичної терапії ми оцінювали за шкалою LEFS (The Lower Extremity Functional Scale) [12], яка містить диференційовану характеристику соціальних і побутових функцій, ступеня рухової активності і нормалізації ходи травмованих спортсменів.

Анатомо-функціональні результати лікування травмованих спортсменів з внутрішньосуглобовими ушкодженнями гомілковостопного суглобу оцінювали за допомогою стандартів оцінки якості лікування ушкоджень і захворювань органів руху і опори, викладених в Наказі МО3 України №41 від 30.03.94 року «Про регламентацію ортопедо-травматологічної допомоги в Україні» відповідно до змін, запропонованих А.В. Калашніковим (2006) [3].

Отриманий в процесі дослідження об'єм цифрового матеріалу був оброблений за допомогою пакету програм обробки даних загального призначення Statisticafor Windows версії 6.0. [9].

\section{Результати дослідження}

Хворим основної групи замість комплексу фізіотерапевтичних процедур і класичного масажу в контрольній групі призначався комплекс, що складався з поєднаного застосування лазневої процедури загальноприйнятої арабської лазні та процедури східного масажу нижніх кінцівок.

Лазнева процедура була застосована у якості підготовчого засобу для подальшого використання, як основного засобу, прийомів східного масажу. Попередній глибокий прогрів м'яких тканин та кістково-суглобового апарату травмованих кінцівок активував внутрішню артеріальну гіперемію, збільшував еластичні якості фіброзної тканини, що дещо знижувало поріг больової чуттєвості при виконанні високо амплітудних рухів. У свою чергу прийоми східного масажу, що використовувалися на тлі дії гіпертермічної лазневої процедури, використовувалися для збільшення амплітуди пасивних рухів у травмованому гомілковостопному суглобі, що призводило до зменшення як структурної, так і функціональної контрактури травмованого суглобу.

Для м'язів та суглобів ураженої кінцівки також призначався східний масаж з акцентом на активізацію крово- та лімфообігу. Фізіотерапевтичні процедури булі замінені процедурами арабської лазні за змішаним типом - східною лазнею з фіксованою технологічною та методичною послідовністю.

Методика лікувального масажу, яка використовувалася під час модифікованої процедури арабської лазні, проводилася в приміщенні лазні на масажній лавці та включала комбінацію прийоми східного і тайського для кінцівок [5]. 
Процедура масажу виконувалася впродовж 30 хвилин. Кожен прийом виконувався тричі, з фіксацією вихідного положення у крайніх положеннях ланок кінцівок на 3-5 с у першій фазі терапії, до 6-8 с у другій фазі, до 8-10 с у третій та четвертій фазах терапії.

Ступінь інтенсивності (сили, що прикладалася) при виконанні прийомів на розтягування зв'язкового апарату суглобів поступово збільшувалася від початкової до четвертої фази терапії та залежала від больового порогу травмованого спортсмена та його загального стану.

Методика масажу була методично розділена на три частини за топографічним та фізіологічним принципом. Спочатку проводили масаж здорової кінцівки, а далі м'язів та суглобів ушкодженої.

Методика східного масажу для травмованих спортсменів основної групи виконувалась в наступній методичній послідовності: розпочинали процедуру масажу обробкою м'язів та суглобів спочатку здорової, а потім ушкодженої кінцівки у вихідному положенні лежачи на животі. У цьому положенні виконували прийоми пресаційного надавлювання та розминання м'язів кінцівки, дозованого згинання, розгинання та відведення кульшових суглобів зі стабільним та м'яким динамічним витягуванням капсульно-зв'язкового апарату цих суглобів.
Масаж м'язів нижньої кінцівки складався з прийомів східного масажу стегна та гомілки у вигляді пресаційного (помпажного) масажу з низкою надавлювань на м'яз, та прийомів класичного масажу, таких як вижимання, захоплюючі та здавлюючі розминання, глибокі класичні захоплюючі та давлючі розминання м'язів та розтирання суглобів.

Далі виконували згинання і розгинання колінного та розтягування капсульно-зв'язкового апарату гомілковостопних суглобів у згинаннях-розгинаннях та відведенні-приведенні зі збільшеною амплітудою, зі стабільним та м'яким динамічним витягуванням капсульнозв'язкового апарату цих суглобів.

Надалі продовжували процедуру масажу суглобів та м'язів спочатку здорової, а потім ушкодженої кінцівки у вихідному положенні лежачи на спині.

У цьому положенні виконували прийоми стабільного надавлювання на м'язи та суглоби кінцівки, дозованого стабільного та м'якого динамічного витягування, згинання та розгинання кульшового, колінного та гомілковостопного суглобів.

Прийоми виконувалися у згинанні-розгинанні та відведенні-приведенні зі збільшеною амплітудою та постійним контролем рівню больових відчуттів травмованого спортсмена.

\section{Результати фізичної реабілітації травмованих спортсменів, одержані за шкалою LEFS}

\begin{tabular}{|l|c|c|c|c|c|c|c|c|}
\hline \multirow{2}{*}{ Результати } & \multicolumn{3}{|c|}{ Контрольна група } & \multicolumn{3}{c|}{ Основна група } \\
\cline { 2 - 10 } & \multicolumn{2}{|c|}{$\begin{array}{c}\text { до } \\
\text { реабілітації }\end{array}$} & \multicolumn{2}{c|}{$\begin{array}{c}\text { після } \\
\text { реабілітації }\end{array}$} & \multicolumn{2}{c|}{$\begin{array}{c}\text { до } \\
\text { реабілітації }\end{array}$} & \multicolumn{2}{c|}{$\begin{array}{c}\text { після } \\
\text { реабілітації }\end{array}$} \\
\cline { 2 - 10 } & абс. & $\%$ & абс. & $\%$ & абс. & $\%$ & абс. & $\%$ \\
\hline Добрі & 2 & 11,1 & 2 & 22,2 & 2 & 11,1 & 13 & 72,2 \\
\hline Задовільні & 10 & 55,6 & 9 & 55,6 & 9 & 50 & 4 & 22,2 \\
\hline Незадовільні & 6 & 33,3 & 7 & 22,2 & 7 & 38,9 & 1 & 5,6 \\
\hline Всього & 18 & 100 & 18 & 100 & 18 & 100 & 18 & 100 \\
\hline
\end{tabular}

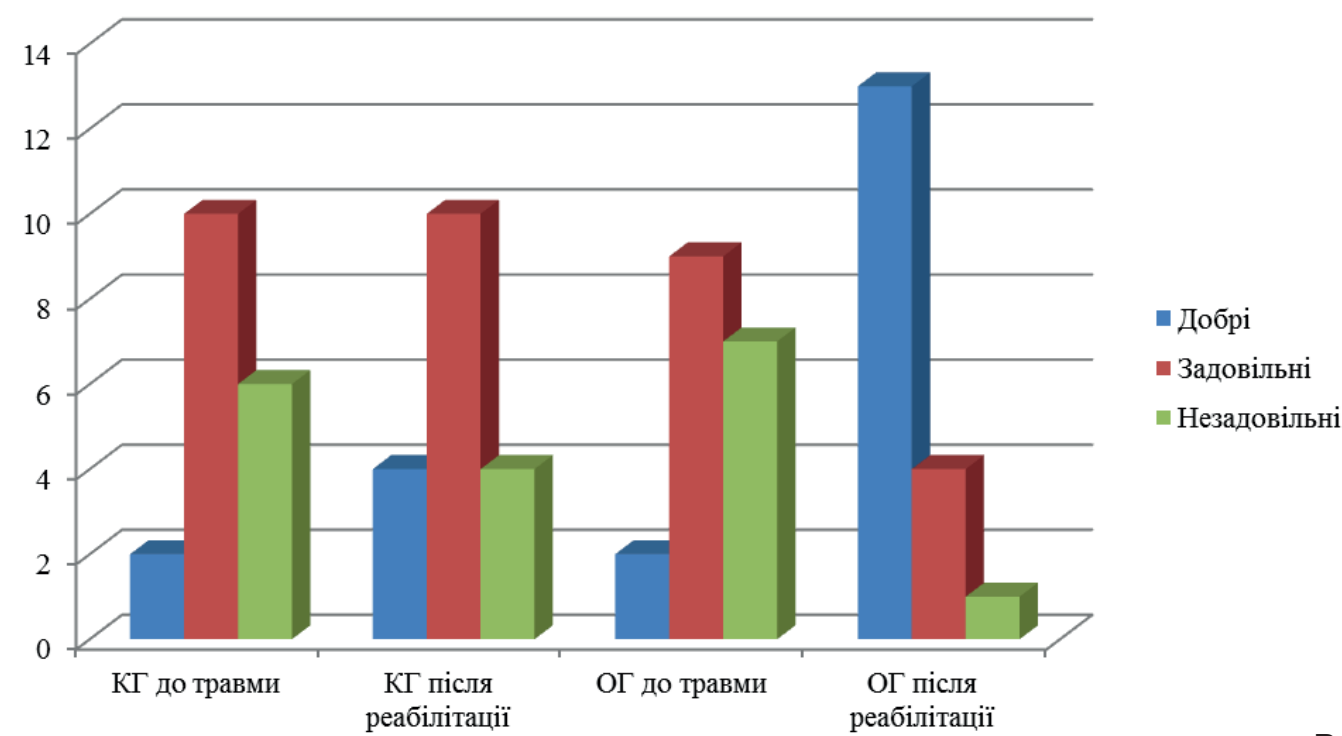

Порівняльні результати реабілітаційних заходів травмованих спортсменів обох клінічних груп за шкалою LEFS 


\section{СЛОБОЖАНСЬКИЙ НАУКОВО-СПОРТИВНИЙ ВІСНИК}

Згинання-розгинання та приведення-відведення стопи у гомілковостопному суглобі проводили як ізольовано, так і з одночасним розгинанням усієї кінцівки та рухами у суміжних суглобах з одночасним їх витягненням. Це дозволяє стабілізувати кровообіг та синхронізувати м'язовий тонус кінцівки. Локальні больові відчуття при цих прийомах значно зменшуються.

Згинання-розгинання та приведення-відведення стопи у гомілковостопному суглобі проводилося як ізольовано, так і в одночасному розгинанні всієї кінцівки та рухом у суміжних суглобах та одночасним її відведенням, приведенням та ротацією. Згинання-розгинання та приведення-відведення стопи у гомілковостопному суглобі проводилося також ізольовано з додатковим навантаженням у особливих чотирьох прийомах, які були використані тільки у 4 фазі комплексу засобів фізичної терапії.

Наприкінці процедури східного масажу, при відсутності індивідуального несприйняття (надмірні лоскотні або значні больові відчуття), для всіх травмованих спортсменів виконувалися прийоми тайського масажу стопи - розгинання та надавлювання в ділянці суглобової щілини пальців, плеснової поверхні стопи та надавлювання на активні точки пальців та підошви стопи (т.з. «плантарний масаж»), які здійснювалися за методикою тайського масажу Ламбера (2005) [4].

Результати проведеної фізичної реабілітації, одержані за шкалою LEFS показали, що після курсу фізичної реабілітації за загальноприйнятою програмою у контрольній групі на 11,1\% зменшилася кількість незадовільних результатів, кількість задовільних результатів не змінилася, та дещо збільшилася кількість добрих результатів - на $11,1 \%$. Результати оцінки даних основної групи переконливо свідчать про суттєве збільшення кількості добрих результатів, а саме в 6,5 разів, та значне зменшення кількості задовільних результатів - майже в 2,3 рази, та, особливо, про зменшення кількості незадовільних результатів (майже в 7 разів), що показує ефективність запропонованої нами програми фізичної реабілітації (табл. 1, рис 1).

3 аналізу оцінки результатів проведеної фізичної реабілітації за методикою А.В. Калашнікова видно, що після курсу фізичної реабілітації за загальноприйнятою програмою кількість незадовільних результатів зменшилася вдвічі, кількість задовільних результатів зменшилася на 22,2\% та в два рази збільшилася кількість гарних результатів (до 66,7\%) (табл. 2, рис 2).

Таблиця 2

Результати фізичної реабілітації травмованих спортсменів, одержані за методикою А.В. Калашнікова

\begin{tabular}{|c|c|c|c|c|c|c|c|c|}
\hline \multirow{3}{*}{ Результати } & \multicolumn{4}{|c|}{ Контрольна група } & \multicolumn{4}{|c|}{ Основна група } \\
\hline & \multicolumn{2}{|c|}{$\begin{array}{c}\text { до } \\
\text { реабілітації }\end{array}$} & \multicolumn{2}{|c|}{$\begin{array}{c}\text { після } \\
\text { реабілітацї }\end{array}$} & \multicolumn{2}{|c|}{$\begin{array}{c}\text { до } \\
\text { реабілітації }\end{array}$} & \multicolumn{2}{|c|}{$\begin{array}{c}\text { після } \\
\text { реабілітації }\end{array}$} \\
\hline & абс. & $\%$ & абс. & $\%$ & абс. & $\%$ & абс. & $\%$ \\
\hline Добрі & 6 & 33,3 & 12 & 66,7 & 7 & 38,9 & 15 & 83,3 \\
\hline Задовільні & 8 & 44,4 & 4 & 22,2 & 6 & 33,3 & 3 & 16,7 \\
\hline Незадовільні & 4 & 22,2 & 2 & 11,1 & 5 & 27,8 & - & - \\
\hline Всього & 18 & 100 & 18 & 100 & 18 & 100 & 18 & 100 \\
\hline
\end{tabular}

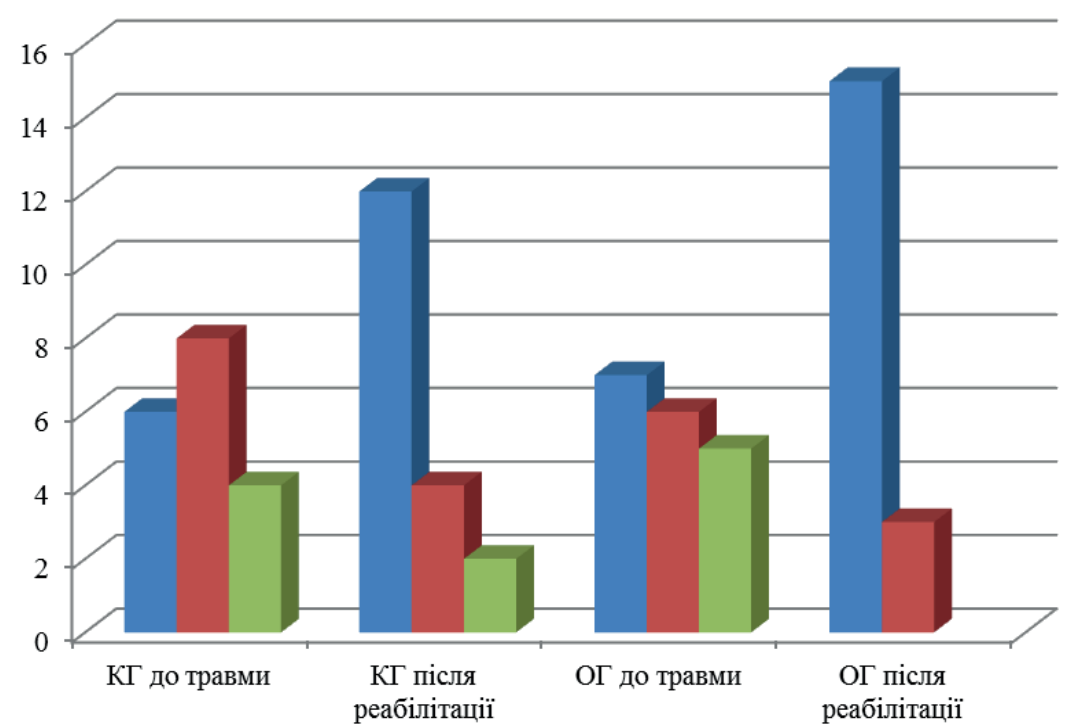

- Добрі

- Задовільні

ш Незадовільні

Рис. 2.

Порівняльні результати оцінки ортопедичного статусу травмованих спортсменів обох клінічних груп за методикою А.В. Калашнікова 
В основній групі спостерігалося значне збільшення частки добрих результатів, а саме в 2,1 рази до $83,3 \%$, за рахунок чого вдвічі зменшилася кількість задовільних результатів до 16,7\%, при повній відсутності незадовільних результатів.

Аналіз результатів проведеної фізичної терапії свідчить, що більш виражені позитивні результати були отримані у травмованих спортсменів основної групи, яким була проведена фізична терапія згідно з запропонованою нами програмою, при позитивній динаміці змін функціонального стану травмованих спортсменів обох клінічних груп.

Крім того у постраждалих основної групи в однакові терміни спостереження спостерігалися достовірно кращі за контрольну групу показники вказаних методик й шкали оцінки результатів, що свідчить про виражену позитивну динаміку стану постраждалих спортсменів після проведеної програми фізичної терапії.

\section{Висновки / Дискусія}

Загальноприйнято, що найважливішою проблемою сучасної фізичної терапії травмованих спортсменів є швидке і повноцінне повернення спортивної працездатності.

Також з багатьох наукових джерел відомо, що ушкодження зв'язково-капсульного апарату гомілковостопного суглоба за поширеністю займають друге місце серед всіх травм суглобів, і травмованим спортсменам необхідно тривале лікування.

Сперечатися у даному випадку доцільно лише з питань саме вибору тактики фізичної терапії залежно від характеру ушкоджень кістково-хрящових структур суглоба. Ефективне повернення до активної професійної діяльності травмованих спортсменів відбувається за умови, якщо до існуючих традиційних підходів і методів фізичної терапії додаються нові технології лікування для прискорення відновних процесів. Авторами дослідження була розроблена і апробована програма фізичної терапії, яка містила методики східного масажу у поєднанні із процедурами східної лазні саме для вирішення завдання скорішого відновлення належного функціонального стану кваліфікованих спортсменів футболістів і повернення їх до продуктивної професійної діяльності.

Заходи традиційної програми фізичної терапії травмованих спортсменів з наслідками внутрішньосуглобових ушкоджень гомілковостопного суглоба, які включали використання методик класичного масажу, за шкалою LEFS дали змогу зменшити кількість незадовільних результатів на $11,1 \%$ у контрольній групі, та кількість добрих результатів подвоїти до 22,2\%.

Заходи програми фізичної терапії, які включали методику східного масажу у поєднанні зі східною лазнею для спортсменів основної групи збільшили кількість добрих результатів на 61,1\%, що зменшило кількість задовільних на 27,8\%, та на 33,3\% незадовільних результатів, що свідчить про об'єктивну ефективність запропонованої нами програми фізичної терапії.

Програма терапії за традиційною програмою дала змогу в контрольній групі зменшити кількість незадовільних та задовільних анатомо-функціональних результатів за методикою А.В Калашнікова на $11,1 \%$ та 22,2\% відповідно, та збільшити кількість добрих до 66,7\%.

У спортсменів основної групи за методикою А.В Калашнікова збільшилася кількість добрих результатів на $44,4 \%$, за рахунок чого на 16,6\% зменшилася кількість задовільних результатів, та була зафіксована відсутність незадовільних результатів, що переконливо демонструє переваги запропонованої програми фізичної терапії.

Для вирішення завдання повернення кваліфікованих спортсменів до активної тренувальної та змагальної діяльності нами була розроблена та об'єктивно успішно втілена в практику програма реабілітаційних заходів із застосуванням методик східного масажу у поєднанні зі східною лазнею, може бути рекомендована до загального використання.

Перспективи подальших досліджень. Впровадження запропонованої програми фізичної терапії спортсменів з внутрішньосуглобовими ушкодженнями гомілковостопного суглоба з використанням процедур модифікованої східної лазні і послідовним використанням процедур з елементами східного масажу у профільних закладах охорони здоров'я України та Лівану.

Конфлікт інтересів. Автори заявляють, що відсутній конфлікт інтересів, який може сприйматись таким, що може завдати шкоди неупередженості статті.

Джерела фінансування. Ця стаття не отримала фінансової підтримки від державної, громадської або комерційної організації.

\section{Список посилань}

1. Белая Н. А. (2001), Лечебная физкультура и массаж. Москва, 272 с.

2. Васичкин В. (2016), Все про массаж. Москва, 304 с.

3. Гайко Г. В., Калашніков А. В., Вдовіченко К. В. (2010), «Вибір методу лікування хворих із діафізарними переломами великогомілкової кістки», Український медичний альманах, 13(1), С. 40-43.

4. Ламбер Дж. (2005), Тайский массаж. Ростов на Дону, 346 с.

5. Меркати М. (2002), Тайский массаж: Шаг за шагом по пути к исцелению. Москва, 176 с.

6. Підкопай Д. О. (2019), Класичний масаж. Харків, 452 с.

7. Погосян М. М. (2002), Лечебный массаж: учебник. Москва, 528 с.

8. Руденко Р. (2013), Масаж. Львів, 302 с.

9. Сергиенко В. И., Бондарева И. Б. (2000), Математическая статистика в клинических исследованиях. Москва, 256 с.

10. Травматологія та ортопедія: підручник / за ред. Голки, Г. Г., Бур'янова, О. А., Климовицького, В. Г. 2-ге вид. Вінниця, 432 с.

11. Хассан Дандаш, Підкопай Д. О. (2016), «Методические особенности физической реабилитации пострадавших с последствиями минно-взрывной травмы», Слобожанський науково-спортивний вісник, № 2, С. 127-131.

12. Binkley J. M., Stratford P. W., Lott S. A., Riddle D. L. (1999), «The Lower Extremity Functional Scale (LEFS): scale development, measurement properties, and clinical application», Physical Therapy, Vol. 79(4), pp. 371-383. 


\title{
СЛОБОЖАНСЬКИЙ НАУКОВО-СПОРТИВНИЙ ВІСНИК
}

13. Crowell M. S., Deyle G. D., Owens J., Gill N. W. (2016), «Manual physical therapy combined with high-intensity functional rehabilitation for severe lower extremity musculoskeletal injuries: a case series», Journal of Manual \& Manipulative Therapy, Vol. 24(1), pp. 34-44.

14. Elsoe R., Ostgaard S. E., Larsen P. (2018), "Population-based epidemiology of 9767 ankle fractures", Foot and ankle surgery, Vol. 24(1), pp. 34-39.

15. Hootman J. M., Dick R., Agel J. (2007), «Epidemiology of collegiate injuries for 15 sports: Summary and recommendations for injury prevention initiatives», Journal of athletic training, Vol. 42, pp. 311-319.

16. McPhail S. M., Williams C. M., Schuetz M., Baxter B., Tonks P., Haines T. P. (2014), «Development and Validation of the Ankle Fracture Outcome of Rehabilitation Measure (A-FORM)», Journal of Orthopaedic \& Sports Physical Therapy, Vol. 44(7), pp. 488-492.

17. Painter E. E., Deyle G. D., Allen C., Petersen E. J., Croy T., Rivera K. P. (2015), «Manual Physical Therapy Following Immobilization for Stable Ankle Fracture: A Case Series», Journal of Orthopaedic \& Sports Physical Therapy, Vol. 45(9), pp. 665-674.

18. Traumatology and orthopedics: textbook (2018) / edited by Golka, G. G., Burianov, O. A., Klimovitsky, V. G., Nova Knyha, 400 p.

Стаття надійшла до редакції: 24.03.2021 р.

Опубліковано: 26.04.2021 p.

\begin{abstract}
Аннотация. Юсеф Шарбель, Татьяна Подкопай, Денис Подкопай. Результаты применения программы физической терапии с использованием методик этнического массажа при повреждениях голеностопного сустава. Цель: оценка результатов физической терапии спортсменов футболистов с внутрисуставными повреждениями голеностопного сустава на амбулаторном этапе при применении мероприятий программы физической терапии с привлечением методик этнического восточного массажа. Материал и методы: в работе проанализированы результаты исследования, которые проводились в г. Бейрут (Ливан), клинике Медицинского центра «Mir Majid Erslan». Эффективность физической терапии 36 футболистов с внутрисуставными повреждениями голеностопного сустава на амбулаторном этапе оценивали по методике А.В. Калашникова и по шкале LEFS. Результаты: установлено, что при положительных изменениях функционального состояния пострадавших спортсменов обеих клинических групп выявлены достоверно лучшие результаты у футболистов основной группы, которым была предложена физическая терапия согласно разработанной нами программы. Выводы: проведенный анализ результатов исследования показал, что у травмированных спортсменов основной группы, при одинаковых сроках и объемах наблюдения, результаты методов исследования были достоверно выше и объективно более выражены, чем в контрольной группе.

Ключевые слова: внутрисуставные повреждения голеностопного сустава, физическая терапия, восточный массаж, восточная баня, амбулаторный этап.
\end{abstract}

\begin{abstract}
Youssef Charbel, Tetiana Podkopai, Denis Podkopai. Results of the application of the physical therapy program using ethnic massage techniques for injuries of the ankle joint. Purpose: to evaluate the results of physical therapy of sportsmen football players with intra-articular injuries of the ankle joint at the outpatient stage when using measures of the physical therapy program using the techniques of ethnic oriental massage. Material and methods: the study analyzes the results of a study conducted in Beirut (Lebanon), the clinic of the Mir Majid Erslan Medical Center. The effectiveness of physical therapy of 36 football players with intraarticular injuries of the ankle joint at the outpatient stage was assessed according to the method of A.V. Kalashnikov and LEFS scale. Results: it was found that with positive changes in the functional state of the injured athletes of both clinical groups, reliably better results were revealed among the football players of the main group, who were offered physical therapy according to the program we developed. Conclusions: the analysis of the research results showed that in the injured athletes of the main group, with the same periods and volumes of observation, the results of the research methods were significantly higher and objectively more pronounced than in the control group.
\end{abstract}

Keywords: intra-articular injuries of the ankle joint, physical therapy, oriental massage, oriental bath, outpatient stage.

\section{References}

1. Belaya, N. A. (2001), Lechebnaya fizkul'tura i massazh. Moskva, 272 p. (in Russ.)

2. Vasichkin, V. (2016), Vse pro massazh. Moskva, 304 p. (in Russ.)

3. Gajko, G. V., Kalashnikov, A. V., Vdovichenko, K. V. (2010), «Vibir metodu likuvannya hvorih iz diafizarnimi perelomami velikogomilkovoï kistki», Ukraïns'kij medichnij al'manah, 13(1), pp. 40-43. (in Ukr.)

4. Lamber, Dzh. (2005), Tajskij massazh. Rostov na Donu, 346 p. (in Russ.)

5. Merkati, M. (2002), Tajskij massazh: SHag za shagom po puti k isceleniyu. Moskva, 176 p. (in Russ.)

6. Pidkopaj, D. O. (2019), Klasichnij masazh. Harkiv, 452 p. (in Ukr.)

7. Pogosyan, M. M. (2002), Lechebnyj massazh: uchebnik. Moskva, 528 p. (in Russ.)

8. Rudenko, R. (2013), Masazh. L'viv, 302 p. (in Ukr.)

9. Sergienko, V. I., Bondareva, I. B. (2000), Matematicheskaya statistika v klinicheskih issledovaniyah. Moskva, 256 p. (in Russ.)

10. Travmatologiya ta ortopediya: pidruchnik / za red. Golki, G. G., Bur'yanova, O. A., Klimovic'kogo, V. G. 2-ge vid. Vinnicya, 432 p. (in Ukr.)

11. Hassan, Dandash, Pidkopaj, D. O. (2016), «Metodicheskie osobennosti fizicheskoj reabilitacii postradavshih s posledstviyami minno-vzryvnoj travmy», Slobozhans'kij naukovo-sportivnij visnik, № 2, pp. 127-131. (in Russ.)

12. Binkley, J. M., Stratford, P. W., Lott, S. A., Riddle, D. L. (1999), «The Lower Extremity Functional Scale (LEFS): scale development, measurement properties, and clinical application», Physical Therapy, Vol. 79(4), pp. 371-383. (in Eng.)

13. Crowell, M. S., Deyle, G. D., Owens, J., Gill, N. W. (2016), «Manual physical therapy combined with high-intensity functional rehabilitation for severe lower extremity musculoskeletal injuries: a case series», Journal of Manual \& Manipulative Therapy, Vol. 24(1), pp. 34-44. (in Eng.)

14. Elsoe, R., Ostgaard, S. E., Larsen, P. (2018), «Population-based epidemiology of 9767 ankle fractures», Foot and ankle surgery, Vol. 24(1), pp. 34-39. (in Eng.)

15. Hootman, J. M., Dick, R., Agel, J. (2007), «Epidemiology of collegiate injuries for 15 sports: Summary and recommendations for injury prevention initiatives», Journal of athletic training, Vol. 42, pp. 311-319. (in Eng.) 


\section{СЛОБОЖАНСЬКИЙ НАУКОВО-СПОРТИВНИЙ ВІСНИК}

16. McPhail, S. M., Williams, C. M., Schuetz, M., Baxter, B., Tonks, P., Haines, T. P. (2014), «Development and Validation of the Ankle Fracture Outcome of Rehabilitation Measure (A-FORM)», Journal of Orthopaedic \& Sports Physical Therapy, Vol. 44(7), pp. 488492. (in Eng.)

17. Painter, E. E., Deyle, G. D., Allen, C., Petersen, E. J., Croy, T., Rivera, K. P. (2015), «Manual Physical Therapy Following Immobilization for Stable Ankle Fracture: A Case Series», Journal of Orthopaedic \& Sports Physical Therapy, Vol. 45(9), pp. 665-674. (in Eng.)

18. Traumatology and orthopedics: textbook (2018) / edited by Golka, G. G., Burianov, O. A., Klimovitsky, V. G., Nova Knyha, 400 p. (in Eng.)

Received: 24.03.2021.

Published: 26.04.2021.

\section{Відомості про авторів / Information about the Authors}

Юсеф Шарбель: Харківська державна академія фізичної культури: вул. Клочківська 99, м. Харків, 61058, Україна.

Юсеф Шарбель: Харьковская государственная академия физической культуры: ул. Клочковская 99, г. Харьков, 61058, Украина.

Youssef Charbel: Kharkiv State Academy of Physical Culture: Klochkivska str. 99, Kharkiv, 61058, Ukraine.

ORCID: https://orcid.org/0000-0002-4442-9509

E-mail: twintracker@gmail.com

Підкопай Тетяна Володимирівна: Харківська державна академія фізичної культури: вул. Клочківська 99, м. Харків, 61058, україна.

Подкопай Татьяна Владимировна: Харьковская государственная академия физической культуры: ул. Клочковская 99, г. Харьков, 61058, Украина.

Tetiana Podkopai: Kharkiv State Academy of Physical Culture: Klochkivska str. 99, Kharkiv, 61058, Ukraine.

ORCID: https://orcid.org/0000-0002-7890-0215

E-mail: alicepodkopay@gmail.com

Підкопай Денис Олегович: к.фіз.вих., Харківська державна академія фізичної культури: вул. Клочківська 99, м. Харків, 61058, Україна.

Подкопай Денис Олегович: к.физ.восп., Харьковская государственная академия физической культуры: ул. Клочковская 99, г. Харьков, 61058, Украина.

Denis Podkopai: PhD (Physical Education and Sport), Kharkiv State Academy of Physical Culture: Klochkivska str. 99, Kharkiv, 61058, Ukraine.

ORCID: https://orcid.org/0000-0001-9845-7639

E-mail: frir@ukr.net 